\title{
PENGGUNAAN CAMPUR KODE DAN ALIH KODE DALAM PROSES PEMBELAJARAN DI SMPN UBUNG PULAU BURU (The Use of Mixing Code and Switching Code in Learning Process at SMPN Ubung Buru Island)
}

\author{
Nanik Indrayani \\ Universitas Iqra Buru \\ JL. Universitas, Namlea, Kabupaten Buru, Maluku \\ Pos-el: nanikindra83@gmail.com
}

(Diterima: 14 November 2017; Direvisi: 20 November 2017; Disetujui: 26 Desember 2017)

\begin{abstract}
Mixing code and switching code are always become strategy in learning process. The aim of the research were describing the form of mixing code and switching code as well as factors that caused them at SMPN Ubung, Lilialy District, Buru Regency, Maluku. This was qualitative descriptive research that studied the phenomenon of linguistic by sociolinguistic approach. The source of data in this research were all the speeches ofof the teachers, as well as all the students who involved in learning process that used mixing code and switching code. Method of data collection was conducted by non-participant observation. Meanwhile, technique of collecting data was done by free conversation, recording, and noting technique. The data was analyzed by qualitative descriptive analysis technique. The results of this study revealed that the forms of mixing code were the insertion of word, repeated word, personal pronoun, and phrase, while switching code were independent clause, coordinative clause, and sentence. The other finding were the factors that lead to mixing code was the influence of first language, no other equivalent, and practical. The factors that led to switching code were considered prestige, offsetting the students' language skill, and teacher emotion. mixing code and switching code occurred in learning process at SMPN Ubung, Lilialy District, Buru Regency, Maluku, by the teachers and students from Indonesian to Ambon Malay dialect or vice versa
\end{abstract}

Keywords: mixing code, switching code, caused factors

\begin{abstract}
Abstrak
Campur kode dan alih kode selalu dijadikan strategi dalam proses pembelajaran. Penelitian ini bertujuan untuk mendeskripsikan bentuk-bentuk campur kode dan alih kode serta faktor-faktor yang menyebabkan terjadinya peristiwa campur kode dan alih kode di SMPN Ubung, Kecamatan Lilialy, Kabupaten Buru, Maluku. Penelitian ini merupakan penelitian deskriptif kualitatif yang mengkaji fenomena kebahasaan dengan pendekatan Sosiolinguistik. Sumber data dalam penelitian ini adalah tuturan-tuturan yang digunakan guru serta semua tuturan siswa yang terlibat dalam proses pembelajaran yang mengandung campur kode dan alih kode. Metode pengumpulan data dilakukan melalui observasi nonpartisipasi. Sementara teknik pengumpulan data dilakukan melalui teknik simak bebas libat cakap, teknik rekam, dan teknik catat. Data yang sudah diklasifikasi kemudian dianalisis dengan teknik analisis deskriptif kualitatif. Hasil penelitian ini mengungkapkan bahwa bentuk-bentuk campur kode yang berupa wujud penyisipan kata, kata ulang, kata ganti orang, dan frasa, sedangkan alih kode berwujud klausa mandiri, klausa koordinatif, dan kalimat. Temuan berikutnya faktor-faktor yang menyebabkan terjadinya campur kode yaitu pengaruh bahasa pertama, tidak ada padanan lain, dan praktis. Adapun faktor-faktor yang menyebabkan terjadinya alih kode yaitu dianggap prestise atau bergengsi, mengimbangi kemampuan berbahasa siswa, dan emosi guru. Campur kode dan alih kode tersebut terjadi dalam proses pembelajaran di SMPN Ubung, Kecamatan Lilialy, Kabupaten Buru, Maluku, yang dilakukan guru dan siswa dari bahasa Indonesia ke dialek Melayu Ambon atau sebaliknya.
\end{abstract}

Kata-kata Kunci: Campur Kode, Alih Kode, faktor-faktor penyebab

\section{PENDAHULUAN}

Sebagai makhluk individu dan makhluk sosial, manusia memiliki keinginan untuk selalu berkomunikasi dan bekerjasama antara sesamanya dengan menggunakan bahasa. Ketika berinteraksi antara pengguna bahasa yang satu dengan pengguna bahasa yang lain akan timbul suatu kontak bahasa. Dengan bahasa seseorang akan memiliki berbagai informasi 
dan ilmu pengetahuan. Bahasa juga merupakan salah satu faktor yang sangat penting dan berpengaruh dalam melahirkan kesadaran bangsa.

Menurut The Ethnologue edisi II dalam Taha (2008:29), jumlah bahasa daerah di Indonesia lebih dari 660 buah, sebagian besar termasuk rumpun bahasa Austronesia. Keanekaragaman bahasa ini mencerminkan kekayaan budaya bangsa Indonesia yang beranekaragam. Perbedaan bahasa dan keanekaragaman budaya itu cermin dalam semboyan bangsa Indonesia, "Bhenika Tunggal Ika", yang berarti dalam keanekaan tetap ada kesatuan.

Bahasa daerah merupakan sarana pendukung kebudayaan daerah diakui keberadaannya oleh Negara. Meskipun kita memiliki bahasa Indonesia sebagai bahasa persatuan namun bahasa daerah itu sendiri merupakan ciri khas atau jati diri suatu masyarakat tertentu yang dituturkan secara turun-temurun dan merupakan bentukwarisan budaya.

Menurut Wijana (2006:88), sesuai dengan penjelasan pasal 36 Undang-Undang Dasar 1945, yang menyatakan "Bahasabahasa daerah yang terdapat di Indonesia yang masih digunakan sebagai sarana komunikasi dan masih dipelihara oleh masyarakat pemakainya, dihargai dan dipelihara oleh negara karena bahasa-bahasa itu adalah bagian dari kebudayaan yang hidup".

Menurut (Saimima, 2007), dialek Melayu Ambon merupakan bahasa yang tergolong sebagai rumpun atau dialek dari bahasa Melayu standar yang dipertuturkan di wilayah Provinsi Maluku yang mencakup kota Ambon, pulau Ambon, pulau-pulau Lease yaitu Saparua, Haruku dan Nusalaut, pulau Buano, pulau Manipa, pulau Kelang, pulau Seram, pulau Buru, serta dipakai pula sebagai bahasa perdagangan atau trade language di Kei, Banda, Kepulauan Watubela, Maluku Tenggara sampai Ke Maluku Barat Daya. Sebelum bangsa Portugis menginjakkan kakinya di Ternate yakni pada tahun 1512, bahasa Melayu telah ada di Maluku dan dipergunakan sebagai bahasa perdagangan.

Menurut Asrif (2016), dalam Seminar dan Dialog Internasional Kemelayuan Indonesia Timur IV di Makassar menyatakan bahwa bahasa Melayu Dialek Ambon sangat prestise atau bergengsi. Karena bahasa Melayu Dialek Ambon sangat prestise dari pada bahasa daerah, sehingga untuk bahasa kesehariannya mereka tidak lagi menggunakan bahasa daerah mereka. Masih menurut Asrif (2016), di Maluku terdapat 49 bahasa daerah. Namun bahasa-bahasa daerah tersebut sudah terancam punah, bahkan sudah ada beberapa bahasa daerah di Maluku yang sudah punah. Di pulau Buru sendiri sudah ada 4 bahasa daerah yang sudah punah.

Punahnya bahasa-bahasa daerah yang ada di Maluku membuktikan bahwa bahasa Melayu Dialek Ambon sangat prestise atau bergengsi dari pada bahasa daerah. Dialek Melayu Ambon banyak mendapatkan kosakata dari bahasa Portugis dan bahasa Belanda. Pulau Ambon pernah dijajah oleh bangsa Portugis dan bangsa Belanda, sehingga kosakata dari kedua bahasa tersebut diserap ke dalam bahasa Melayu dialek Ambon namun sesuai dengan logat setempat.

Masyarakat yang berdomisili di desa Ubung Kecamatan Lilialy Kabupaten Buru Maluku terdiri atas berbagai suku, budaya, dan bahasa, sehingga mereka adalah masyarakat multilingual. Artinya mereka layak menguasai minimal dua bahasa atau lebih yakni; bahasa daerah, bahasa Melayu dialek Ambon, dan bahasa Indonesia.

Sebuah fenomena menarik yang saat ini terjadi yaitu banyak orang melakukan pergantian kode, baik alih kode (code switching) maupun campur code (code mixing) dalam berkomunikasi dengan orang lain. Kode merupakan varian yang nyata dipakai. Dengan kata lain, kode adalah bagian dari sebuah tuturan bahasa, kode biasanya berbentuk varian bahasa yang secara nyata dipakai berkomunikasi anggota suatu masyarakat bahasa. 
Paul dalam Kridalaksana (2009:7) berpendapat, "alih kode pada hakikatnya merupakan pergantian pemakaian bahasa atau dialek", secara singkat memberi definisi alih kode sebagai penggunaan variasi bahasa lain untuk menyesuaikan diri dengan peran atau situasi lain. Alih kode menurut Suwandi (2012:86) dapat terjadi dalam sebuah percakapan ketika seorang pembicara menggunakan sebuah bahasa dan mitra bicaranya menjawab dengan bahasa lain.

Menurut Taha (1985:23), alih kode antarbahasa dapat terjadi pada penutur yang menguasai dua bahasa atau lebih, sedangkan alih kode antarvariasi atau antarragam bahasa dapat terjadi pada penutur dwidialek. Walaupun rumusan-rumusan pengertian alih kode tersebut berbeda antara satu dengan yang lain namun yang jelas adalah bahwa fenomena alih kode ini melibatkan pergantian pemakaian dua kode bahasa atau variasi bahasa. Oleh sebab itu, alih kode dapat terjadi antara dua bahasa yang berlainan, baik yang serumpun maupun tidak.

Dalam situasi formal kita dituntut untuk menggunakan bahasa Indonesia yang baik dan benar. Begitupun di lingkungan sekolah khususnya di ruang kelas, bahasa Indonesia yang baik dan benar wajib digunakan. Pemakaian Bahasa Indonesia digunakan sebagai bahasa pengantar pada setiap jenis dan jenjang pendidikan. Hal ini tertuang dalam Bab XV, Pasal 36 UUD 1945 yang menjelaskan bahwa bahasa pengantar yang digunakan dalam proses belajar mengajar di sekolah adalah bahasa Indonesia.

Namun permasalahan yang terjadi yaitu ada kalanya pada saat proses pembelajaran, baik guru maupun siswa tidak menyadari akan adanya penggunaan campur kode dan alih kode. Hal ini pun sering terjadi di SMPN Ubung, Kecamatan Lilialy, Kabupaten Buru, Maluku, mereka menggunakan campur kode dan alih kode dari bahasa Indonesia dan bahasa Melayu dialek Ambon yang digunakan secara bergantian dalam proses pembelajaran.
Campur kode dan alih kode yang digunakan baik oleh guru maupun siswa agar proses pembelajaran bisa berlangsung dengan lancar.

Dampak negatif dari penggunaan campur kode dan alih kode dalam proses pembelajaran dapat mengganggu tujuan pembelajaran terutama yang berkaitan dengan perolehan keterampilan berbahasa Indonesia terhadap siswa yakni ; (1), siswa kurang mampu memahami sehingga tidak bisa membedakan ketika menggunakan bahasa Indonesia di dalam ruang kelas maupun di luar kelas, dengan kata lain siswa tidak mengerti perbedaan antara menggunakan bahasa Indonesia di tempat yang formal dan tidak formal. (2), siswa kurang mampu dalam menggunakan bahasa Indonesia dengan baik dan benar. Dengan kata lain siswa atau peserta didik belum memiliki kemampuan yang memadai dalam menangkap paparan lisan dan tulis, begitu pula kemampuan mengungkapkan pengalaman dan hasil belajarnya dengan bahasa Indonesia yang baik dan benar. (3), rendahnya penguasaan bahasa Indonesia atau kosakata para peserta didik atau siswa. Kebiasaan siswa beralih kode dan bercampur kode di dalam kelas karena mengikuti kebiasaan para guru, juga faktor kebiasaan mereka menggunakan bahasa daerah ketika berada di rumah.

Berikut contoh data yang menunjukkan fenomena campur kode dan alih kode yang terjadi dalam proses pembelajaran di SMPN Ubung, Kecamatan Lilialy, Kabupaten Buru, Maluku.

Guru : Apa kabar semuanya?

Siswa : Baik ibu.

Guru : Baiklah anak-anak, sebelum ibu melanjutkan materi tentang penggunaan huruf kapital, ibu ingin tahu sapa (siapa) yang seng hader (tidak hadir) hari ini?

Guru : Baiklah anak-anak, sebelum ibu melanjutkan materi tentang penggunaan huruf kapital, ibu ingin tahu siapa yang tidak hadir hari ini? 
Siswa : Katong maso samua (kita semua masuk) ibu.

Siswa : Kita semua masuk ibu.

Guru : Tentang tugas yang ibu su kase par kamong kamareng, (sudah berikan untuk kamu orang kemarin) apakah kamong su biking $\boldsymbol{k a}$ balong (kamu orang sudah kerjakan atau belum)?

Guru : Tentang tugas yang ibu sudah berikan untuk kalian kemarin apakah kalian sudah kerjakan atau belum?

Siswa : Suda ibu. (sudah).

Siswa : Sudah ibu.

Guru memulai proses pembelajaran dengan menggunakan bahasa Indonesia ragam resmi. Kemudian guru menggunakan campur kode dialek Melayu Ambon dengan mengatakan "Baiklah anak-anak, sebelum ibu melanjutkan materi tentang penggunaan huruf kapital, ibu ingin tahu sapa (siapa) yang seng hader (tidak hadir) hari ini?" Bentuk campur kode yang digunakan dalam tuturan guru tersebut berwujud kata, dan frasa yaitu "sapa (siapa), dan seng hadir (tidak datang).

Sebelum guru melanjutkan dalam hal ini menerangkan materinya, terlebih dahulu guru ingin mengetahui keadaan siswanya. Kemudian siswapun menjawab dengan campur kode yang dengan mengatakan "Katong maso samua" yang artinya kita orang atau kita semua masuk. Ditinjau dari bentuknya tuturan yang digunakan siswa tersebut menggunakan alih kode yang berwujud klausa mandiri.

Selanjutnya tuturan guru yang menggunakan alih kode yaitu yang ditandai dengan tuturan "su kase par kamong kamareng, yang artinya sudah berikan untuk kamu orang kemarin apakah "kamong su biking ka balong” artinya kamu orang sudah kerjakan atau belum? Bentuk alih kode dalam tuturan guru berwujud klausa koordinatif.

Adapun yang menyebabkan guru dan siswa tersebut menggunakan campur kode dan alih kode dalam tuturannya yaitu faktor kebiasaan menggunakan dialek Melayu Ambon saat berada di rumah, guru mengimbangi kemampuan berbahasa siswa, dan pengaruh bahasa pertama. Guru dan siswa tinggal dan bermukim di tempat yang sama dan menggunakan bahasa yang sama saat berada di rumah yaitu dialek Melayu Ambon.

Berdasarkan latar belakang tersebut, pemakaian campur kode dan alih kode dialek Melayu Ambon dalam proses pembelajaran di SMPN Ubung, kecamatan Lilialy, Kabupaten Buru, Maluku menarik dan perlu diteliti karena campur kode dan alih kode sering dijadikan metode atau strategi dalam proses pembelajaran, sehingga bisa berakibat tidak akan tercapai tujuan pemakaian bahasa Indonesia yang baku, cermat, tepat, dan efesien dalam komunikasi, yaitu pemakaian bahasa Indonesia dengan baik dan benar yang mengandung makna baik bila sesuai dengan konteks situasi pemakaiannya dan benar bila mengikuti kaidah bahasa Indonesia baku.

Adapun rumusan masalah yang dapat diangkat dalam penelitian ini yaitu:

1. Bagaimanakah bentuk-bentuk campur kode dan alih kode bahasa Melayu dialek Ambon dalam kegiatan pembelajaran di SMPN Ubung, Kecamatan Lilialy, Kabupaten Buru, Maluku?

2. Faktor-faktor apa saja yang menyebabkan terjadinya campur kode dan alih kode bahasa Melayu dialek Ambon dalam kegiatan pembelajaran di SMPN Ubung, Kecamatan Lilialy, Kabupaten Buru, Maluku?

Penelitian ini akan lebih menitikberatkan aspek kebahasaan dalam proses pembelajaran di SMPN Ubung di Kecamatan Lilialy Kabupaten Buru Maluku yang bertujuan;

1. mendeskripsikan bentuk-bentuk campur kode dan alih kode bahasa Melayu dialek Ambon dalam kegiatan pembelajaran di SMPN Ubung, Kecamatan 
Lilialy, Kabupaten Buru, Maluku; dan

2. mendeskripsikan faktor-faktor yang menyebabkan terjadinya campur kode dan alih kode bahasa Melayu dialek Ambon dalam kegiatan pembelajaran di SMPN Ubung, Kecamatan Lilialy, Kabupaten Buru, Maluku.

Penelitian ini dapat memberikan dua manfaat yaitu manfaat teoretis dan manfaat praktis.

Manfaat teoretis

Penelitian ini dapat menambah khasanah teori sosiolinguistik, khususnya mengenai bentuk-bentuk dan faktor-faktor penyebab campur kode dan alih kode. Sebagai acuan dan bandingan bagi peneliti-peneliti kedwibahasaan untuk pengembangan sosiolinguistik khususnya mengenai campur kode dan alih kode.

Manfaat praktis

Penelitian ini dapat menambah informasi tentang penggunaan bahasa khususnya bentuk-bentuk dan faktok-faktor penyebab campur kode dan alih kode.

\section{LANDASAN TEORI}

Menurut Chaer dalam (Leonie Agustina 2004:3) sosiolinguistik adalah bidang ilmu antardisiplin yang memelajari bahasa dalam kaitannya dengan penggunaan bahasa itu di dalam masyarakat. Demikian juga menurut Nababan (1991:2), sosiolinguistik adalah studi atau pembahasan bahasa sehubungan dengan penutur bahasa itu sebagai anggota masyarakat, seorang penutur bahasa adalah anggota masyarakat-tutur atau lebih tepat sosiolinguistik itu memelajari atau mengkaji bahasa dan dimensi kemasyarakatan.

Menurut Kridalaksana (2009:2), variasi bahasa berdasarkan pemakai bahasa dapat dibedakan atas:

1. Dialek regional, yaitu variasi bahasa yang dipakai di daerah tertentu. Variasi regional membedakan bahasa yang dipakai di satu tempat dengan yang dipakai di tempat lain, walaupun variasi-variasinya berasal dari satu bahasa. Jadi dikenal bahasa Melayu dialek Ambon atau dialek Melayu Ambon, dialek Jakarta, atau bahasa Melayu dialek Medan.

2. Dialek sosial, yaitu dialek yang dipakai oleh kelompok sosial tertentu atau menandai stratum sosial tertentu, misalnya dialek wanita, dialek remaja.

3. Dialek temporal, yaitu dialek yang dipakai pada kurun waktu tertentu, misalnya dialek Melayu zaman Sriwijaya, dialek Melayu zaman Abdullah'

4. Idiolek, yaitu keseluruhan ciriciri bahasa seseorang. Sekalipun kita semua berbahasa Indonesia namun kita masing-masing memiliki ciri-ciri khas pribadi dalam lafal, tatabahasa, atau pilihan dan kekayaan kita.

Suwito (1983:78) mengemukakan batasan yang tidak jauh berbeda, yakni bahwa istilah kode dimaksudkan untuk menyebut salah satu variasi dalam hierarki kebahasaan. Hierarki kebahasaan ini dimulai dari bahasa sebagai level yang paling atas disusul dengan kode yang terdiri dari varianvarian dan ragam-ragam, serta gaya-gaya, dan register sebagai sub-sub kodenya. Dari pendapat di atas, dapat dibuat rangkuman tentang kode yaitu kode yang mengacu pada bahasa dan variasi bahasa, kode merupakan varian yang secara nyata dipakai, dan kodekode tersebut memiliki arti.

Menurut Appel dalam Chaer (2004:106) mendefinisikan alih kode itu sebagai,"gejala peralihan pemakaian bahasa karena berubahnya situasi". Berbeda dengan Appel yang mengatakan alih kode itu terjadi antarbahasa, Hymes dalam Chaer (2004:107) mengatakan alih kode itu bukan hanya terjadi antarbahasa, tetapi dapat juga terjadi antara ragam-ragam atau gaya-gaya yang terdapat dalam satu bahasa. 
Gumperz (1972:66) berpendapat bahwa alih kode menyandarkan pada penjajaran yang bermakna apa yang oleh pembicara dilakukan, baik secara sadar maupun bawah sadar sebagai rangkaian yang dibentuk menurut kaidah internal dua sistem gramatikal yang berbeda. Pada kasus lain, alih kode percakapan dapat didefinisikan sebagai penjajaran (juxtaposition) dalam penukaran bagian ujaran yang sama dari ujaran yang memiliki dua sistem atau subsistem gramatikal yang berbeda, atau suatu percakapan berlangsung dalam dua kode atau lebih.

Hymes dalam Suwito (1996:81) mengemukakan bahwa alih kode adalah istilah umum untuk menyebutkan pergantian (peralihan) pemakaian dua bahasa atau lebih dari suatu ragam.

Paul dalam Kridalaksana (2009:7) berpendapat, "alih kode pada hakikatnya merupakan pergantian pemakaian bahasa atau dialek", secara singkat memberi definisi alih kode sebagai penggunaan variasi bahasa lain untuk menyesuaikan diri dengan peran atau situasi lain. Alih kode menurut Suwandi (2012:86) dapat terjadi dalam sebuah percakapan ketika seorang pembicara menggunakan sebuah bahasa dan mitra bicaranya menjawab dengan bahasa lain.

Menurut Taha (1985), alih kode antarbahasa dapat terjadi pada penutur yang menguasai dua bahasa atau lebih, sedangkan alih kode antarvariasi atau antarragam bahasa dapat terjadi pada penutur dwidialek. Walaupun rumusan-rumusan pengertian alih kode tersebut berbeda antara satu dengan yang lain namun yang jelas adalah bahwa fenomena alih kode ini melibatkan pergantian pemakaian dua kode bahasa atau variasi bahasa. Oleh sebab itu, alih kode dapat terjadi antara dua bahasa yang berlainan, baik yang serumpun maupun tidak.

Berdasarkan batasan tersebut dapat disimpulkan bahwa alih kode selain dapat berupa alternasi pemakaian dua variasi atau ragam satu bahasa, juga dapat berupa alternasi pemakaian dua bahasa atau lebih.
Alih kode merupakan salah satu aspek kebergantungan bahasa dalam masyarakat multilingual. Artinya dalam masyarakat multilingual mungkin sekali seorang penutur menggunakan berbagai kode dalam tindak tuturnya. Alih kode tidak dapat dilepaskan kehadirannya dari masyarakat multilingual, karena seorang penutur tidak akan menggunakan satu bahasa secara mutlak murni tanpa sedikitpun memanfaatkan bahasa atau unsur bahasa lain. Peristiwa peralihan kode ini bergantung pada keadaan atau keperluan berbahasa itu.

Campur kode merupakan salah satu aspek saling kebergantungan bahasa di dalam masyarakat bilingual (dwibahasa). Jadi, hampir tidak mungkin di dalam masyarakat bilingual seorang penutur menggunakan satu bahasa secara mutlak tanpa sedikit pun memanfaatkan bahasa atau unsur bahasa lain. Campur kode (codemixing) terjadi apabila seorang penutur menggunakan suatu bahasa secara dominan mendukung suatu tuturan disisipi dengan unsur bahasa lainnya. Hal ini biasanya berhubungan dengan karakteristk penutur, seperti latar belakang sosial, tingkat pendidikan, rasa keagamaan.

Nababan (1991:32) berpendapat bahwa ciri yang menonjol dalam campur kode adalah kesantaian atau situasi informal. Dalam situasi yang formal jarang terdapat campur kode. Suwito (1983:78-79) menyebutkan beberapa macam campur kode yang berdasarkan unsur-unsur kebahasaan yang terlibat di dalamnya terdiri dari penyisipan unsur-unsur yang berwujud kata; penyisipan unsur-unsur yang berwujud frasa; penyisipan unsur-unsur yang berwujud bentuk baster; penyisipan unsurunsur yang berwujud pengulangan kata; penyisipan unsur-unsur yang berwujud ungkapan atau idiom; serta penyisipan unsur-unsur yang berwujud klausa. Namun bisa terjadi karena keterbatasan bahasa, ungkapan dalam bahasa tersebut tidak ada padanannya, sehingga ada keterpaksaan menggunakan bahasa lain, walaupun hanya mendukung satu fungsi. 
Gejala alih kode biasanya diikuti dengan gejala campur kode, Thelander dalam Chaer (2010:115) menjelaskan perbedaan alih kode dan campur kode, bila di dalam suatu peristiwa tutur terjadi peralihan dari satu klausa bahasa ke klausa bahasa lain, maka peristiwa yang terjadi adalah alih kode. Tetapi apabila di dalam suatu peristiwa tutur, klausa-klausa maupun frasa-frasa yang digunakan terdiri atas klausa dan frasa campuran (hybrid cllauses, hybrid phrases), dan masing-masing klausa atau frasa itu tidak lagi mendukung fungsi sendiri-sendiri, maka peristiwa yang terjadi adalah campur kode, bukan alih kode. Thelander selanjutnya mengatakan, memang ada kemungkinan terjadi perkembangan dari alih kode ke campur kode. Perkembangan ini misalnya, dapat dilihat kalau ada usaha untuk mengurangi kehibridan klausa-klausa atau frasa-frasa yang digunakan, serta memberi fungsi-fungsi tertentu sesuai dengan keotonomian bahasanya masingmasing.

Kemudian Nababan (1991:32) mengatakan campur kode, yaitu suatu keadaan berbahasa lain ialah bilamana orang mencampur dua (atau lebih) bahasa atau ragam bahasa dalam suatu tindak bahasa tanpa ada sesuatu dalam situasi berbahasa yang menuntut percampuran bahasa itu. Maksudnya adalah keadaan yang tidak memaksa atau menuntut seseorang untuk mencampur suatu bahasa ke dalam bahasa lain saat peristiwa tutur sedang berlangsung. Jadi, penutur dapat dikatakan secara tidak sadar melakukan percampuran serpihanserpihan bahasa ke dalam bahasa asli. Dalam campur kode penutur menyelipkan unsur-unsur bahasa lain ketika sedang memakai bahasa tertentu. Unsur-unsur tersebut dapat berupa kata-kata, tetapi dapat juga berupa frasa atau kelompok kata. Jika berwujud kata biasanya gejala itu disebut peminjaman. Hal yang menyulitkan timbul, ketika memakai kata-kata pinjaman tetapi kata-kata pinjaman ini sudah tidak dirasakan sebagai kata asing melainkan dirasakan sebagai bahasa yang dipakai.
Sebagai contoh si A berbahasa Indonesia. Kemudian ia berkata "sistem operasi komputer ini sangat lambat", dari sini terlihat si A banyak menggunakan katakata asing yang dicampurkan ke dalam bahasa Indonesia. Namun, ini tidak dapat dikatakan sebagai gejala campur kode atau pun alih kode. Hal ini disebabkan penutur jelas tidak menyadari kata-kata yang dipakai adalah kata-kata pinjaman, bahkan ia merasa semuanya merupakan bagian dari bahasa Indonesia karena proses peminjaman tersebut sudah terjadi sejak lama.

Menurut Suwito (1983:78-80), berdasarkan unsur-unsur kebahasaan yang terlibat di dalam bentuk-bentuk campur kode dapat dibedakan menjadi; penyisipan unsur-unsur yang berwujud kata, penyisipan unsur-unsur berwujud frasa, penyisipan unsur-unsur berwujud klausa, penyisipan unsur-unsur berwujud perulangan kata, penyisipan unsur-unsur berwujud ungkapan atau idiom.

Menurut Ba'dulu (2004:6), bahwa definisi kata suatu bentuk bebas yang terkecil, yaitu suatu unsur yang dapat muncul tersendiri dalam berbagai posisi dalam kalimat. Kata ulang adalah perulangan kata dengan mengulang keseluruhan atau sebagian bentuk dasar). Kata ganti orang atau pronominal persona adalah pronominal yang dipakai untuk mengacu ke orang. Pronomina persona ini dapat digolongkan menjadi tiga macam; (1) pronominal persona pertama, (2) pronominal persona kedua, (3) pronominal persona ketiga.

Menurut Putrayasa (2010:3) frasa adalah kelompok kata yang menduduki sesuatu fungsi di dalam kalimat. Dengan kata lain frasa adalah satuan gramatikal yang terdiri atas dua kata atau lebih yang tidak melampaui batas fungsi unsur klausa. Dapat disimpulkan bahwa campur kode menurut unsur-unsur kebahasaannya, berwujud; kata dasar, kata jadian, perulangan kata atau reduplikasi, dan frasa.

Bentuk-bentuk tersebut akan diuji dalam analisis alih kode dan campur kode dalam kegiatan pembelajaran di SMP Negeri 
Ubung Kecamatan Lilialy Kabupaten Buru Maluku sehingga akan diketahui ciri khas yang berbeda dalam setiap masyarakat tutur.

\section{METODE}

Jenis penelitian kualitatif dengan menggunakan metode deskriptif adalah penelitian yang memaparkan, menganalisis, mengklasifikasi data yang telah diperoleh, yang dilakukan semata-mata berdasarkan pada fakta-fakta yang ada atau fenomena yang terjadi secara nyata atau empirik. Dengan demikian, data dalam penelitian ini mendeskripsikan fenomena campur kode dan alih kode bahasa Indonesia ke dialek Melayu Ambon yang terjadi dalam proses pembelajaran di kelas VII, VIII, dan kelas IX, di SMPN Ubung, Kecamatan Lilialy, Kabupaten Buru, Maluku.

Sumber data penelitian ini, yaitu tuturan guru mata pelajaran Bahasa Indonesia, IPA, IPS, dan Penjas, serta tuturan semua siswa yang terlibat dalam proses pembelajaran. Adapun jenis data penelitian ini, yaitu data lisan berupa tuturan yang mengandung bentuk-bentuk dan faktor-faktor yang menyebabkan terjadinya campur kode dan alih kode dari bahasa Indonesia ke dialek Melayu Ambon dalam proses pembelajaran yang digunakan oleh guru dan siswa di SMPN Ubung, Kecamatan Lilialy, Kabupaten Buru, Maluku.

Adapun sampel yang digunakan dalam penelitian ini adalah sebagian dari keseluruhan tuturan yang mengandung bentuk-bentuk yang faktor-faktor penyebab terjadinya campur kode dan alih kode yang digunakan oleh guru dan siswa dalam proses pembelajaran di SMPN Ubung kecamatan Lilialy kabupaten Buru.

Metode simak adalah metode yang digunakan untuk memperoleh data dengan melakukan penyimakan terhadap penggunaan bahasa. Tuturan-tuturan yang terjadi dalam proses pembelajaran yang digunakan oleh guru dan siswa sebagai narasumber tersebut diamati, dan disimak. Tuturan-tuturan yang disimak dan diamati tersebut, dikhususkan pada tuturan yang mengandung bentuk-bentuk dan faktorfaktor yang menyebabkan terjadinya campur kode dan alih kode bahasa Indonesia ke dialek Melayu Ambon dalam proses pembelajaran kemudian ditandai, serta didokumentasikan untuk diinventarisasikan sebagai data dalam penelitian ini.

Semua tuturan yang berupa percakapan guru dan siswa dalam proses pembelajaran yang terdapat dalam transkrip rekaman, diidentifikasi yang mengandung campur kode dan alih kode. Data-data yang sudah diidentifikasi sebelumnya, diklasifikasikan berdasarkan permasalahan yang ada, yakni bentuk-bentuk dan faktorfaktor penyebab terjadinya campur kode dan alih kode dalam proses pembelajaran. Data yang sudah diklasifikasi, kemudian dianalisis dengan mendeskripsikan secara terperinici permasalahan yang terdapat dalam data yang telah dikumpulkan berdasarkan teori yang berkaitan dengan campur kode dan alih kode, sebagai dasar dalam pedoman menganalisis.

\section{PEMBAHASAN}

Hasil penelitian ini secara umum berkaitan dengan aspek kebahasaan yang terjadi dalam proses pembelajaran di SMPN Ubung, Kecamatan Lilialy, Kabupaten Buru, Maluku, dan aspek-aspek teoretis yang menjadi unsur penting yang menyebabkan tetap digunakannya alih kode dan campur ketika dalam proses pembelajaran. Hasil penelitian ini mengungkapkan bahwa bentuk-bentuk campur kode yang berwujud penyisipan kata, kata ulang, kata ganti orang, dan frasa, sedangkan alih kode berwujud klausa mandiri, klausa koordinatif, dan kalimat. Temuan berikutnya faktor-faktor yang menyebabkan terjadinya campur kode yakni; pengaruh bahasa pertama, tidak ada padanan lain, dan praktis. Adapun faktorfaktor yang menyebabkan terjadinya alih kode yakni; dialek Ambon memiliki nilai prestise atau bergengsi, mengimbangi kemampuan berbahasa siswa, dan emosi guru. 
Data campur kode dan alih kode berjumlah 90 data namun yang dianalisis berjumlah 40 data, dari total 28 kali pertemuan. Data tersebut diperoleh dari mata pelajaran Bahasa Indonesia $8 \mathrm{X}$ pertemuan, IPA $8 X$ pertemuan, IPS $8 x$ pertemuan, dan Penjas 4X pertemuan. Setiap pertemuan selama 2 X45 menit, sehingga keseluruhan waktu yang digunakan untuk penelitian ini selama 2520 menit.

Penggunaan campur kode dan alih kode dalam proses pembelajaran dilakukan oleh guru dan siswa namun penggunaannya didominasi oleh guru. Pada saat menyampaikan materi ataupun dalam tanya jawab, guru kerap kali menggunakan campur kode dan alih kode dari bahasa Indonesia ke dialek Melayu Ambon yang dilakukan secara bergantian. Adapun alasan yang bisa menjelaskan guru melakukan campur kode dan alih kode dalam proses pembelajaran karena guru memahami siswa masih dominan menggunakan dialek Melayu Ambon.

Campur kode dan alih kode yang digunakan oleh guru selain alasan tersebut juga karena adanya alasan tertentu seperti keadaan emosi diri karena merasa jengkel dan kesal terhadap siswa, menjelaskan kembali atau mengulang kembali materi yang sudah dijelaskan sehingga siswa mampu memahami maksud yang diutarakan oleh guru dengan lebih baik serta lebih cepat menangkap materi secara jelas. Hal ini memudahkan peserta didik dalam memahami tuturan guru untuk menjawab pertanyaan baik yang dijawab secara serempak maupun individu, sehingga proses pembelajaran bisa berjalan dengan baik.

Penggunaan campur kode dan alih kode yang sering digunakan dalam proses pembelajaran menyebabkan pengaruh positif dan negatif. Pengaruh positifnya yaitu siswa lebih paham dengan maksud yang disampaikan oleh guru, sehinga proses pembelajaran dapat berlangsung dengan lancar. Pengaruh negatif dari penggunaan campur kode dan alih kode tersebut dapat mengganggu tujuan pembelajaran terutama yang berkaitan dengan perolehan keterampilan berbahasa Indonesia terhadap siswa yakni;

1. Siswa kurang mampu memahami sehingga tidak bisa membedakan ketika menggunakan bahasa Indonesia di dalam kelas maupun di luar kelas, dengan kata lain siswa tidak mengerti perbedaan antara menggunakan bahasa Indonesia di tempat yang formal dan tidak formal,

2. Rendahnya penguasaan bahasa Indonesia atau kosakata para peserta didik atau siswa. Dengan demikian tidak akan tercapai tujuan pemakaian bahasa Indonesia yang baku, cermat, tepat, dan efesien dalam komunikasi, yaitu pemakaian bahasa Indonesia dengan baik dan benar yang mengandung makna baik bila sesuai dengan konteks situasi pemakaiannya dan benar bila mengikuti kaidah. Untuk lebih jelasnya akan dipaparkan dalam pembahasan.

Dalam penelitian ini ditemukan bahwa bentuk-bentuk campur kode yang berwujud penyisipan kata, kata ulang, kata ganti orang, dan frasa, sedangkan alih kode berwujud klausa mandiri, klausa koordinatif, dan kalimat. Faktor-faktor yang menyebabkan terjadinya campur kode yakni; pengaruh bahasa pertama, tidak ada padanan lain, dan praktis, sedangkan yang menyebabkan terjadinya alih kode yakni; bahasa Melayu dialek Ambon memiliki nilai prestise atau bergengsi, mengimbangi kemampuan berbahasa siswa, dan emosi guru. Proses pembelajaran di SMPN Ubung antara guru dan siswa menggunakan bahasa Indonesia sebagai alat tutur dan seringkali bercampur dan beralih kode ke dalam dialek Melayu Ambon ataupun sebaliknya.

Guru dan siswa tinggal dan bermukim di wilayah yang sama yakni; wilayah kecamatan Lilialy, kabupaten Buru. Mereka juga menggunakan bahasa yang sama yakni; bahasa Melayu dialek Ambon untuk bahasa keseharian mereka. Hal itu menyebabkan 
guru bertutur menggunakan bahasa Indonesia dan dialek Melayu Ambon secara bergantian sehingga terjadi campur kode dan alih kode. Berikut akan diuraikan bentukbentuk campur kode dan alih kode, serta faktor-faktor penyebabnya terjadinya campur kode dan alih kode dalam proses pembelajaran di SMPN Ubung, Kecamatan Lilialy, Kabupaten Buru, Maluku.

\section{Bentuk-bentuk Campur Kode berwujud Penyisipan Kata \\ Kata adalah suatu unit dari suatu} bahasa yang mengandung arti dan terdiri atas satu atau lebih morfem, dan dapat berdiri sendiri. Kata merupakan satuan terbesar dalam morfologi dan dianggap sebagai satuan terkecil dalam sintaksis. Umumnya kata terdiri atas satu akar kata tanpa atau dengan afiks. Berikut data yang menunjukkan peristiwa campur kode berwujud kata.

Guru : Kalian su siap tarima pelajaran hari ini?

Guru : Kalian sudah siap menerima mata pelajaran hari ini?

Siswa : Iya ibu. Iya ibu

Guru memulai proses pembelajaran dengan menggunakan bahasa Indonesia ragam resmi. Namun guru tidak menyadari kalau dalam tuturannya tersebut sudah bercampur kode dari bahasa Indonesia bercampur ke dialek Melayu Ambon. Dalam tuturan data (1) guru mengatakan kalian "su" dan "tarima" yang artinya (sudah) dan (menerima). Campur kode tersebut dilakukan oleh guru ketika proses pembelajaran akan di mulai. Campur kode yang berbentuk serpihan kata dialek Melayu Ambon tersebut untuk menanyakan kesiapan siswanya dalam menerima pelajaran hari ini. Adapun guru menggunakan campur kode dari bahasa Indonesia ke dialek Melayu Ambon ketika dalam proses pembelajaran tersebut secara tidak sadar.

\section{Bentuk Campur Kode berwujud Penyisipan Kata Ulang}

Kata Ulang atau reduplikasi adalah kata yang mengalami proses perulangan, baik sebagian ataupun seluruhnya dengan disertai perubahan bunyi ataupun tidak. Istilah bentuk ulang dapat berupa ulangan bentuk dasar seutuhnya atau sebagian dengan atau tanpa imbuhan dan pengubahan bunyi. Bentuk campur kode berwujud penyisipan kata ulang dapat dilhat dalam data berikut.

Guru : Selamat pagi dan apa kabar adeade?

Guru : Selamat pagi dan apa kabar adikadik?

Siswa : Selamat pagi ibu.

Guru : Sehat semuanya?

Selamat pagi ibu.

Sehat semuanya?

Siswa : Alhamdulillah sehat ibu.

Alhamdulillah sehat ibu.

Peristiwa campur kode dalam data (2) tersebut berwujud kata ulang. Guru menggunakan tuturan dari bahasa Indonesia ke dialek Melayu Ambon yang berupa kata ulang yaitu “ade-ade” yang artinya adikadik. Penggunaan campur kode yang digunakan oleh guru tersebut untuk menghilangkan jarak sehingga tercipta suasana keakraban antara guru dan siswa supaya proses pembelajaran bisa berjalan dengan baik.

\section{Bentuk Campur Kode berwujud Penyisipan Kata Ganti Orang}

Kata ganti adalah kata yang digunakan untuk menggantikan kata benda atau orang. Kata ganti orang merupakan kata yang digunakan untuk menggantikan kata benda orang dengan kata benda lain. Berikut data yang merupakan kata ganti orang.

Guru : Selamat pagi, apa kabar adik-adik?

Guru : Selamat pagi, apa kabar adik-adik?

Siswa : Baik ibu.

Siswa : Baik ibu.

Guru : Iya, katong su bisa molai

deng materi hari ini.

Guru : Iya, kita sudah bisa memulai dengan materi hari ini?

Siswa : Bisa ibu.

Siswa : Bisa ibu. 
Penggunaan campur kode dalam proses pembelajaran yang terdapat dalam data (3) tersebut berwujud kata ganti. Tuturan dalam data tersebut mengalami peristiwa campur kode dari bahasa Indonesia ke dialek Melayu Ambon yang berwujud kata ganti orang pertama jamak yakni "katong” yang artinya kita orang atau dalam bahasa Indonesia baku artinya kita. Campur kode yang dilakukan guru tersebut untuk menciptakan suasana keakraban antara guru dan siswa agar proses pembelajaran bisa berjalan dengan baik.

\section{Bentuk Campur Kode berwujud Penyisipan Frasa}

Frasa adalah kelompok kata yang menduduki sesuatu fungsi di dalam kalimat. Adapun campur kode yang berwujud penyisipan frasa dapat dilihat dalam percakapan berikut.

Guru : Kamong (kamu orang) ada yang tahu kanapa de seng maso? (mengapa dia tidak masuk)?

Guru : Kalian ada yang tahu mengapa dia tidak masuk?

Siswa : Dia ada saki.

Siswa: Dia sedang sakit pak.

Campur kode yang berwujud penyisipan frase bahasa Indonesia ke dialek Melayu Ambon digunakan guru dan siswa secara bergantian. Berdasarkan data (4) di atas guru bertanya kepada siswanya mengapa temannya tidak masuk sekolah hari ini. Siswa menjawab pertanyaan gurunya dengan menggunakan campur kode yang berupa frasa dialek Melayu Ambon ditandai dengan penggunaan “ada saki” yang artinya sedang sakit. Dalam bahasa Melayu dialek Ambon kata "ada" yang memiliki makna "sedang".

Siswa menggunakan campur kode karena menjawab pertanyaan dari guru yang menggunakan campur kode. Peristiwa campur kode yang dituturkan guru supaya mudah dipahami oleh siswa sehingga mereka bisa dengan mudah menjawab pertanyaan, baik yang dijawab secra serempak maupun individu.

\section{Bentuk-Bentuk Alih Kode yang Berwujud Klausa Mandiri}

Klausa adalah satuan gramatikal yang berupa kelompok kata, sekurang-kurangnya terdiri atas subjek dan predikat dan berpotensi menjadi kalimat. Klausa mandiri atau klausa bebas merupakan klausa yang kehadirannya dapat berdiri sendiri. Klausa mandiri berpotensi untuk menjadi kalimat tuggal. Bentuk alih kode yang berwujud klausa mandiri seperti dalam data berikut:

Guru : Kamong samua lia ka lao di lingkungan sekolah.

Guru : Kalian semua melihat ke luar di lingkungan sekolah.

Siswa: Iya ibu.

Peristiwa alih kode berwujud klausa mandiri dilakukan oleh penutur dengan menyisipkan klausa dari dialek Melayu Ambon ke bahasa Indonesia dalam dalam proses pembelajaran. Para guru menggunakan alih kode dan campur kode pada saat mengajar memiliki alasan tersendiri. Guru berlih kode yang berwujud klausa mandiri dalam data (5) yang ditandai dengan "kamong samua lia ka lao" yang artinya kalian semua melihat ke luar. Sementara alasan yang bisa menjelaskan mengapa guru melakukan alih kode karena guru memahami siswa masih dominan menggunakan dialek Melayu Ambon sehingga guru pada saat menyampaikan materi sering menggunakan bahasa Indonesia dan dialek Melayu Ambon yang dilakukan secara bergantian.

6. Bentuk-Bentuk Alih Kode yang Berwujud Klausa Koordinatif

Klausa koordinatif dapat dijumpai dalam kalimat plural atau majemuk setara. Dalam kalimat plural atau majemuk setara, semua klausanya koordinatif. Klausa tersebut dinamakan klausa koordinatif karena secara gramatik dihubungkan secara koordinatif oleh pehubung-penghubung koordinatif dan, atau, tetapi, lagi pula, lalu, namun, untuk, sebaliknya, malahan, dan lain-lain.

Guru : Kemudian ibu kase tugas par

kamong untuk mengarang bebas, lalu kanapa buku tugas yang di 
kumpul hanya ini saja, yang laeng mana? (karena hanya ada beberapa buku yang di kumpul di meja guru). Angka tangan yang seng kumpul tugas.

Guru : Kemudian ibu memberikkan tugas untuk kalian untuk mengarang bebas, lalu mengapa buku tugas yang di kumpul hanya ini saja, yang lain mana? (karena hanya ada beberapa buku yang di kumpul di meja guru). Angkat tangan yang tidak mengumpulkan tugas.

Siswa : Hanya ada beberapa siswa yang mengangkat tanganya).

Guru : Kamong dengar samua bagemana kamong mo pintar kalo bagini kamong pung cara, suru biking tugas tar biking, bagemana mo jadi polisi, tentara, bidan, dokter.

Dalam data (6) yang dipaparkan terdapat peristiwa alih kode yang berwujud klausa koordinatif. Peristiwa tersebut ditandai dengan dimasukkannya tuturan "kase tugas par kamong” artinya memberi tugas untuk kamu orang atau kalian. Ciri dari klausa koordinatif disini adalah adanya penghubung yaitu "untuk". Guru sudah memberikan tugas kepada semua siswa beberapa minggu yang lalu namun hanya beberapa orang saja yang sudah mengerjakan tugas. Guru beralih kode dari bahasa Indonesia ke dialek Melayu Ambon dalam tuturanya karena memiliki tujuan untuk mempertegas tuturannya supaya mudah dipahami oleh siswanya, sehingga proses pembelajaran bisa berlangsung dengan baik.

\section{Bentuk-Bentuk Alih Kode yang Berwujud Kalimat}

Kalimat adalah satuan bahasa yang secara relatif berdiri sendiri, memiliki intonasi final, dan baik secra aktual maupun potensi terdiri atas klausa. Kalimat adalah gabungan dari kata, frasa, klausa, yang dimulai dengan huruf kapital dan diakhiri dengan tanda titik, tanda tanya, atau tanda seru. Berikut data yang menunjukkan bentuk-bentuk alih kode yang berwujud kalimat.

Guru : Ketua kelas mana?

Siswa : Saya ibu guru

Guru : Ibu guru mau pi ruma saki tolong ose tulis di papan tulis ka seng se baca par tamang-tamang, ibu sampe pariksa kamong pung catatan.

Guru : Ibu guru akan pergi ke rumah sakit tolong kamu menulis di papan tulis kalau tidak kamu membacakan untuk teman-teman, setelah ibu datang periksa kamu orang punya buku catatan.

Siswa : Tapi seng ada spidol ibu, akang su abis.

Siswa : Tetapi tidak ada spidol ibu, dia sudah habis.

Guru : Kalo bagitu se pi ambe spidol di kantor do.

Guru : Kalau demikian kamu pergi mengambil spidol di kantor dulu.

Dalam (7) tersebut terdapat peristiwa alih kode yang berupa kalimat. Peristiwa tersebut ditandai dengan dimasukkannya tuturan "Kalo bagitu se pi ambe spidol di kantor do" artinya kalau demikian kamu pergi mengambil spidol di kantor dulu. Agar proses pembelajaran tetap berlangsung walaupun tidak ada seorang guru di dalam kelas karena guru pergi ke rumah sakit, maka guru memerintahkan kepada ketua kelas untuk mencatat materi yang akan di ajarkan hari ini. Ketua kelas menjawab spidol di dalam kelas sudah habis, maka guru memerintahkan kepada ketua kelas untuk mengambil spidol di kantor dengan menggunakan alih kode.

Penggunaan alih kode dialek Melayu Ambon dalam tuturan guru tersebut memiliki tujuan untuk mempertegas tuturannya supaya mudah dipahami oleh siswanya dalam hal ini ketua kelas.

penelitian menunjukkan adanya peristiwa campur kode dan alih yang 
dilakukan oleh guru dan siswa saat proses pembelajaran. Adapun penyebab campur kode yang dilakukan oleh guru dan siswa dipengaruhi oleh faktor pengaruh bahasa pertama, tidak ada padanan lain, dan praktis.

\section{Faktor Pengaruh Bahasa Pertama}

Bahasa pertama merupakan bahasa yang dipelajari sejak lahir. Bahasa pertama ini berhubungan dengan karakteristik penutur, seperti latar belakang bahasa. Misalnya, seorang guru atau penutur yang memiliki latar belakang bahasa pertama yang sama dengan siswa atau mitra tuturnya, hal ini dapat mengakibatkan mereka melakukan campur kode ketika berkomunikasi. Untuk lebih jelasnya akan diparakan dalam tuturan-tuturan yang terdapat dalam data berikut ini.

Guru : Sekarang giliran (guru menyebut salah satu nama siswa ) maju untuk membacakan karangannya.

Siswa : (Maju dan membaca hasil karangannya). Adik saya

tanggalang di aer maseng. Dia bernama Fitri. Dia berteriak minta tolong, kemudian saya menggeget adik saya di aer maseng. Lalu dia lari-lari sampe tasonto deng batu.

Siswa : (Maju dan membaca hasil karangannya). Adik saya tenggelam di laut. Dia bernama Fitri. Dia berteriak minta tolong, kemudian saya menarik adik saya di laut. Lalu dia lari-lari sampai tersentuh dengan batu.

Dalam proses pembelajaran mata pelajaran Bahasa Indonesia. seperti yang tampak dalam data (8) di atas sudah terjadi fenomena campur kode. Guru bertutur dengan menggunakan bahasa Indonesia ragam resmi ketika menerangkan mata pelajaran dalam proses pembelajaran. Minggu lalu guru menyuruh siswa untuk membuat tugas tentang mengarang. Kemudian gurupun memanggil nama-nama siswa satu-persatu untuk maju dan membacakan hasil karangannya. Siswa yang dipanggil namanya maju dan membacakan hasil karangannya dengan menggunakan campur kode.

Campur kode yang digunakan dalam tuturan tersebut dengan dimasukkannya kata "tanggalang, aer maseng, dan menggeget" yang artinya tenggelam, laut, dan menarik. Hasil karangan seharusnya menggunakan bahasa Indonesia ragam resmi atau bahasa Indonesia baku. Namun campur kode yang dituturkan siswa tersebut karena masih terpengaruh dengan bahasa pertama sehingga ketika dalam proses pembelajaran mereka masih tetap melakukan.

\section{Memiliki Nilai Prestise}

Masyarakat yang tinggal di wilayah Maluku khususnya pulau Buru menganggap bahasa Melayu dialek Ambon memiliki nilai prestise dibandingkan dengan bahasa daerah. Anak-anak dan para pemuda tidak bisa menggunakan bahasa daerahnya. Dalam situasi non formal mereka menggunakan bahasa Melayu dialek Ambon untuk berkomunikasi.

Hal inilah yang menyebabkan punahnya beberapa bahasa daerah yang ada di Maluku, selain itu karena mereka menganggap bahasa melayu dialek Ambon memiliki nilai prestise dibandingkan dengan bahasa daerah, sehingga dalam proses pembelajaran baik guru maupun siswa sering menggunakan bahasa Melayu dialek Ambon dan bahasa Indonesia yang digunakan secara bergantian. Pembicara atau penutur dalam hal ini guru kerap kali melakukan alih kode untuk memeroleh keuntungan atau manfaat dari tindakannya tersebut. Alih kode yang digunakan biasanya dilakukan penutur dalam keadaan sengaja.

Faktor penyebab terjadinya alih kode dalam proses pembelajaran, penutur dalam hal ini guru yang dengan sengaja beralih kode terhadap lawan tutur atau siswa karena memiliki tujuan tertentu, misalnya karena dialek Melayu Ambon dianggap memiliki nilai prestise dari pada bahasa daerah. Alih kode dari bahasa Indonesia ke dialek Melayu Ambon atau sebaliknya dapat dilihat pada contoh data berikut: 
Guru

: Masi inga ka

seng pelajaran minggu lalu?

Guru

: $\frac{\text { Masih ingat }}{\text { tidak }}$ pelajaran minggu lalu?

Siswa

: Iya masih ibu.

Dalam data (9) tuturan tersebut mengandung alih kode yang dituturkan oleh guru. Penggunaan alih kode berwujud klausa yang dituturkan guru tersebut ditandai dengan “Masi inga $\boldsymbol{k a}$ seng”, yang artinya masih ingat atau tidak. Guru bertanya kepada siswa tentang pelajaran minggu lalu. Agar proses pembelajaran tidak tegang, dan siswa mudah mengingat materi yang sudah diajarkan dalam minggu lalu, penutur atau guru beralih kode dari bahasa Indonesia ke dialek Melayu Ambon.

Dialek Melayu Ambon merupakan bahasa sehari-hari bagi guru dan siswa dan mereka menganggap dialek tersebut sangat bergengsi. Selain hal tersebut, guru bertutur dengan menggunakan alih kode dialek Melayu Ambon supaya proses pembelajaran bisa berlangsung dengan lancar

\section{Tidak ada Padanan Lain}

Latar belakang kebiasaan penutur dan lawan tutur dapat menjadi penyebab seseorang melakukan campur kode. Baik penutur maupun orang yang menjadi pendengar atau mitra tutur yang memiliki kebiasaan sama menggunakan bahasa yang sama saat berada di rumah, sehingga membuat seseorang terkadang mengalami kesulitan untuk mencari padanan bahasa yang sedang digunakan. Selain itu seseorang berkeinginan untuk menjelaskan maksud atau menafsirkan sesuatu juga, dapat menjadi salah satu faktor latar belakang penutur melakukan campur kode.

Guru : Sekarang giliran (guru menyebut salah satu nama siswa ) maju untuk membacakan karangannya.

Siswa : (Maju dan membaca hasil karangannya). Adik saya tanggalang (tenggelam) di aer maseng (laut). Dia bernama Fitri. Dia berteriak minta tolong, kemudian saya menggeget (menarik) adik saya di aer maseng (laut). Lalu dia lari-lari sampe (sampai) tasonto (tersentuh) deng (dengan) batu.

Siswa : (Maju dan membaca hasil karangannya). Adik saya tenggelam di laut. Dia bernama Fitri. Dia berteriak minta tolong, kemudian saya menarik adik saya di laut. Lalu dia lari-lari sampai tersentuh dengan batu.

Peristiwa campur kode yang terjadi dalam data (9), dilakukan oleh siswa dalam proses pembelajaran saat siswa membacakan hasil karangannya. Tuturan campur kode yang dilakukan siswa dengan mengatakan "menggeget" yang dalam bahasa Indonesia yang bermakna "menarik" dalam hal ini sang kakak menarik tangan adiknya, dan "tasonto" yang dalam bahasa Indonesia berarti "tersentuh" atau terantuk. Campur kode yang digunakan siswa dari bahasa Indonesia ke bahasa Melayu dialek Ambon. Siswa menggunakan campur kode karena tidak memiliki padanan bahasa lain.

\section{Praktis}

Supaya bahasa yang digunakan singkat, dan mudah diucapkan, guru maupun siswa di SMPN Ubung, sering menggunakan kata-kata dari dialek Melayu Ambon. Adapun kata-kata yang sering digunakan diantaranya yaitu:

Guru : Hari ini kita akan membahas tentang "Ceritera Tentang Pengalaman yang Berkesan". Ayo (guru menyebut nama salah satu siswa untuk berceritera tentang pengalamannya).

Siswa : Assalammualaikum warahmatullahi wabarakaatu

Siswa : Waalaikum salam warahmatulalah wabarakaatu.

Siswa: Pada hari minggu saya dengan ayah saya pergi mengail. Setelah itu kami melihat orang mengambil ikan. Langsung saya pung (punya) ehe (siswa lupa) punya bapak berkata. Ayo kita ikut orang itu supaya jangan orang itu 
mengambil ikan kita karena orang itu jahat. Langsung saya dengan saya pung (punya) bapak pigi (pergi) ikut.

Siswa: Pada hari minggu saya dengan ayah saya pergi mengail. Setelah itu kami melihat orang mengambil ikan. Langsung saya punya ehe (siswa lupa) punya bapak berkata. Ayo kita ikut orang itu supaya jangan orang itu mengambil ikan kita karena orang itu jahat. Langsung saya dengan saya punya bapak pergi ikut.

Peristiwa tutur dalam data (10) tersebut merupakan tuturan siswa dalam proses pembelajaran dengan materi ceritera "pengalaman yang berkesan". Guru memanggil nama siswa untuk maju dan berceritera tentang pengalamnnya yang berkesan. Setelah guru memanggil namanya kemudian, siswapun maju untuk berceritera. Dalam tuturannya siswa sudah bercampur kode dengan dimasukkannya kata "pung dan pigi" yang artinya punya dan pergi.

Campur kode yang dituturkan siswa tersebut dari bahasa Indonesia ke dialek Melayu Ambon. Siswa menggunakan campur kode yang berwujud penyisipan kata tersebut karena pengaruh bahasa pertama. Baik guru maupun siswa berlatar belakang bahasa yang sama ketika berada di rumah dengan menggunakan bahasa pertama mereka yaitu dialek Melayu Ambon sebagai bahasa sehari-hari.

\section{PENUTUP}

Berdasarkan hasil dan pembahasan dapat dikemukakan simpulan penelitian sebagai berikut. Bentuk-bentuk campur kode berwujud penyisipan kata, dan frasa, sedangkan bentuk alih kode berwujud klausa dan kalimat. Faktor-faktor yang menyebabkan terjadinya campur kode yaitu; pengaruh bahasa pertama, tidak ada padanan lain, praktis, sedangkan faktor yang menjadi penyebab terjadinya alih kode yaitu; bahasa Melayu dialek Ambon dianggap prestise atau bergengsi, mengimbangi kemampuan berbahasa siswa, emosi guru.
Hasil penelitian ini belum mampu mendeskripsikan secara menyeluruh fenomena campur kode dan alih kode yang terjadi dalam proses pembelajaran di SMPN Ubung, Kecamatan Lilialy, Kabupaten Buru, Maluku. Dengan keterbatasan pengetahuan penulis, penelitian yang dilakukan belum sepenuhnya mencapai sasaran yang diinginkan. Keterbatasan penulis dapat dikatakan dari segi pengumpulan data yang tidak menggunakan triangulasi method. Data yang diperoleh hanya di dalam kelas saja, sehingga data agak terbatas atau kekayaan jenis data agak terbatas. Bila dilihat dari segi bentuk-bentuk atau faktorfaktor yang menyebabkan terjadinya campur kode dan alih kode, secara terori hadirnya orang ketiga, dan berubahnya situasi sangat memungkinkan bila penelitian dilakukan diluar kelas.

Untuk itu disarankan bagi peneliti selanjutnya yang akan meneliti tentang campur kode dan alih kode dalam proses pembelajaran disarankan untuk meneliti selain di dalam kelas, meneliti juga di luar kelas.

\section{DAFTAR PUSTAKA}

Asrif. 2016. "Revitalisasi Bahasa Daerah Di Maluku Berbasis Komunitas." Studi Kasus di Negeri HaruUkui dan di Negeri Hitu Lama.

Chaer \& Abdul. 2004. Linguistik Umum. Jakarta: Rineka Cipta.

Hymes \& Chaer 2010. Sosiolingustik Perkenalan Awal. Jakarta Rineka Cipta.

Gumperz, \& Hymes. 1982. Direction In Sociolinguistics. The Ethnography of Commonication New York: Halt Rinehart and Winstoh Inc.

Kridalaksana. 2009. Pembentukan Kata dalam Bahasa Indonesia. Jakarta: Gramedia Pustaka Utama.

Mahsun. 1992. Metode Penelitian Bahasa. Tahapan, Strategi, dan Tekniknya. Depok: PT

Mahsun. 2005. Metode Penelitian Bahasa. Tahapan, Strategi, dan Tekniknya. Depok: PT Grafindo Persada. 
Muhammad. 2011. Metode Penelitian Bahasa. Jogjakarta: Ar-Ruzz Media.

Muhammad. 2014. Metode Penelitian Bahasa. Jogjakarta: Ar-Ruzz Media.

Suwito. 1983. Pengantar Awal Sosiolinguistik (Teori dan Problema). Surakarta: Henary Offset.

Chaer \& Abdul. 2004. Linguistik Umum. Jakarta: Rineka Cipta.

Hymes \& Chaer. 2010. Sosiolingustik Perkenalan Awal. Jakarta Rineka Cipta.

Gumperz, \& Hymes. 1982. Direction In Sociolinguistics. The Ethnography of Commonication New York: Halt Rinehart and Winstoh Inc.

Kridalaksana. 2009. Pembentukan Kata dalam Bahasa Indonesia. Jakarta: Gramedia Pustaka Utama.
Mahsun. 1992. Metode Penelitian Bahasa. Tahapan, Strategi, dan Tekniknya. Depok: PT

Mahsun. 2005. Metode Penelitian Bahasa. Tahapan, Strategi, dan Tekniknya. Depok: PT Grafindo Persada.

Muhammad. 2011. Metode Penelitian Bahasa. Jogjakarta: Ar-Ruzz Media.

Muhammad. 2014. Metode Penelitian Bahasa. Jogjakarta: Ar-Ruzz Media.

Suwito. 1983. Pengantar Awal Sosiolinguistik (Teori dan Problema). Surakarta: Henary Offset.

Taha. 1985. Alih kode dan Campur Kode. Makassar: Badan Penerbit UNM.

Taha. 2008. Gapura Bahasa. Kumpulan Makalah Pilihan tentang Bahasa dan Pengajaran. Makassar: Badan Penerbit UNM. 